\title{
STATISTIK PENDIDIKAN 2
}

\author{
MUH FADLI FAJRIN
}

18210020

$\underline{\text { Muhfadlifajrin1234@gmail.com }}$ 


\section{BAB I \\ PENDAHULUAN}

\section{A. Latar Belakang}

Pengukuran variable adalah proses pemberian nilai atau atribut pada suatu objek. Terdapat Empat Jenis Skala Pengukuran Variabel yaitu Nominal, Ordinal, Interval, Ratio. Skala yang paling rendah adalah Nominal dan yang tertinggi adalah Skala Ratio.

Statistik Deskriptif difokuskan untuk merangkum data yang dikumpulkan dari sampel.

Statistik Inferensial Menggeneralisasikan Statistik yang di peroleh dari sampel ke populasi umum yang menjadi sampel.

Statistik Paramentrik yaitu ilmu Statistik yang mempertimbangkan jenis sebaran atau distribusi data, yaitu apakah data menyebar secara normal atau tidak.

Statistik non Paramentrik yaitu Statistik bebas sebaran (tidak mengsyaratkan bentuk sebaran parameter populasi, baik normal atau tidak). 


\section{B. TUJUAN PENULISAN}

Artikel ini membahas beberapa pokok materi statistik diantaranya sebagai berikut:

1. Jenis variable dan skala pengukuran

2. Perbedaan statistik deskriptif dan inferensial

3. Statistik paramentrik dan nonparamentrik 


\section{BAB II}

\section{PEMBAHASAN}

\section{A. Jenis-Jenis Variable dan Skala Pengukuran}

a. Jenis-jenis variabel

1. Variabel Independen

Variabel Independen atau yang sering disebut dengan variabel bebas merupakan variabel yang mempengaruhi atau menjadi sebab perubahannya.

contoh: variable independen atau variable $\mathrm{X}$ adalah variable yang memberi pengaruh terhadap variable lain. Dalam penelitian ini yang menjadi variable $\mathrm{X}$ adalah "penerapan strategi pembelajaran kreatifproduktif"

\section{Variabel Dependen}

Variabel Dependen atau yang sering disebut dengan variabel terikat merupakan variabel yang dipengaruhi atau yang menjadi akibat perubahannya.

Contoh: variable dependen atau variable $\mathrm{Y}$ yaitu variable yang dipengaruhi oleh variable bebas. Variable dalam penelitian ini adalah “ Hasil belajar matematika" 


\section{Variabel Moderator}

Variabel Moderator merupakan variabel yang mempengaruhi (memperkuat dan memperlemah) hubungan antara variabel bebas dan variabel terikat.

Contoh 1:Hubungan suami dan istri akan semakin baik (kuat) kalau memiliki anak, dan akan semakin renggang kalau ada pihak ke tiga yang ikut mencampuri.

Contoh 2: Hubungan Motivasi dan Prestasi belajar akan semakin kuat (baik) bila peran Guru dalam menciptakan iklim belajar sangat baik, dan hubungan semakin rendah bila peran guru kurang baik dalam menciptakan iklim belajar.

\section{Variabel Intervening}

Variabel intervening adalah variabel yang secara teoritis mempengaruhi hubungan antara variable independen dan dependen, tetapi tidak dapat diamati dan diukur.

Contoh : antara variable bebas dan terikat, sehingga variable bebas dan terikat tidak langsung mempengaruhi berubahnya atau timbulnya variable terikat.

\section{Variabel Kontrol}

Variabel kontrol merupakan variabel yang dikendalikan atau dibuat konstan sehingga hubungan variabel independen terhadap dependen tidak dipengaruhi oleh faktor luar yang tidak diteliti. 
Contoh : Variabel kontrol sering digunakan oleh peneliti, bila akan melakukan penelitian yang bersifat membandingkan, melalui penelitian eksperimen.

b. Skala Pengukuran.

Ada empat jenis skala pengukuran, yaitu:

\section{Skala Nominal}

Skala Nominal adalah skala yang disusun menurut kategorinya atau fungsi bilangan hanya sebagai simbol untuk membedakan sebuah karakteristik dengan karakteristik lainnya. Ciri-ciri skala nominal adalah :
a. Angka yang tertera hanya bentuk label/kategorisasi
b. Tidak dapat dilakukan operasi matematika hitung
c.Tidak memiliki nilai nol yang mutlak atau absolut
d. Tidak memiliki urutan atau ranking

Contoh skala nominal

diantaranya adalah suku bangsa, agama, jenis kelamin, jenis pekerjaan, dll. Data tersebut dikategorikan dalam bentuk angka, misalnya PNS diberi angka 1 dan Pegawai Swasta diberi angka 2.

\section{Skala Ordinal}

Skala ordinal adalah skala yang didasarkan pada ranking diurutkan dari jenjang yang lebih tinggi sampai jenjang terendah ataupun sebaliknya. 
Contoh skala ordinal

adalah mengukur tingkat prestasi kerja, kepangkatan militer, mengukur prestasi kejuaraan, status sosial. Data tersebut tidak memiliki jarak yang pasti dalam pengkategorisasiannya, hanya berupa jenjang yang diurutkan.

\section{Skala Interval}

Skala interval adalah skala yang menunjukkan jarak anatara satu dengan yang lain dan memiliki bobot yang sama.

\section{Contoh skala interval}

adalah temperatur dan suhu, skor IQ, kelompok skor ujian. Data dalam contoh skala ordinal memiliki jarak yang pasti dalam pengkategorisasiannya dan memiliki bobot atau nilai yang sama.

\section{Skala Ratio}

Skala ratio adalah skala pengukuran yang memiliki nilai nol mutlak dan mempunyai jarak yang sama.

\section{Contoh skala ratio}

diantaranya adalah berat badan, tinggi badan, jarak, timbangan berat. Data tersebut memiliki nilai nol yang mutlak dan bisa dilakukan operasi hitung atasnya. Nol mutlak dalam artian apabila berat badan adalah nol, maka seseorang tidak memiliki berat badan. 


\section{B. Perbedaan Statistik Deskriptif dan Statistik Inferensial}

Statistik deskriptif hanya terbatas pada menyajikan data bentuk table, diagram, grafik, dan besaran lain . Sedangkan Statistik inferensial selain mencakup statistik deskriptif juga mampu dipakai untuk melakukan estimasi dan penarikan kesimpulan statistik inferensia melalui tahap uji hipotesis dan uji statistika .

\section{a. Statistik Deskriptif}

adalah metode yang berkaitan dengan pengumpulan / penyajian data hingga memberi informasi yang berguna

Contoh : Tabel

Diagram

Grafik

Besaran-besaran lain di majalah dan Koran-koran

b. Statistika Inferensial

adalah Sebuah metode yang mampu dipakai untuk menganalisis kelompok kecil dari data induknya atau sampel yang diambil dari populasi sampai pada peramalan dan penarikan kesimpulan pada kelompok data induknya atau populasi .

Contoh : Catatan kelulusan selama lima Tahun terakhir pada sebuah Sekolah Menegah Atas menunjukan bahwa 72\% diantara siswa SMA tersebut lulus dengan nilai yang memuaskan .

\section{Statistik Parametrik dan Nonparametrik}

1. Statistik Parametrik mempunyai beberapa unsur -unsur dari model penguji dengan statistik parametrik, diantaranya

- Objek pengamatan harus saling independen. Artinya pemilihan sembarang kasus dari populasi untuk dimasukan dalam sampel tidak boleh menimbulkan bias pada kemungkinan-kemungkinan bahwa kasus tidak boleh mempengaruhi skor yang diberikan kepada kasus lainnya.

- Objek pengamatan harus ditarik dari populasi yang berdistribusi normal.

- Populasi-populasi dimana objek pengamatan ditarik harus memiliki varians yang sama .

- Variabel-variabel yang terlibat harus setidaknya dalam skala interval, sehingga memungkinkan digunakannya penanganan secara ilmu hitung terhadap skor-skornya ( menambah , membagi, menemukan rata-rata) 
- Rata-rata populasi normal dan bervarians sama itu harus juga merupakan kombinasi linier dari efek-efek yang ditimbulkan . Artinya, efek-efek itu harus bersifat penjumlahan.

- Contoh : Penggunaan Statistik parametrik seperti pada uji t dan F, yang aplikasinya banyak diterapkan semisal pada analisis regresi,path analisis, rancangan percobaan, analisis faktor (CFA), structural equation modeling(SEM).

a. Keuntungan Tes Statistik Non Parametrik

- Pernyataan kemungkinan yang diperoleh dari sebagian besar tes statistik non parametrik adalah kemungkinan-kemungkinan yang eksas, tidak peduli bagaimana bentuk distribusi populasi yang merupakan induk sampel-sampel yang kita tarik.

- Jika sampelnya sekecil $\mathrm{N}=6$, hanya tes statistik non parametrik yang dapat digunakan kecuali kalau sifat distribusi populasinya diketahui secara pasti.

- Metode statistik non parametrik dapat digunakan untuk mengarap data hanya merupakan klasifikasi semata, yakni yang diukur dalam skala nominal.

- Terdapat tes statistik non parametrik untuk menggarap sampel-sampel yang terdiri dari observasi-observasi dari beberapa populasi yang berlainan. Tidak ada satu pun di antara tes parametrik dapat digunakan untuk data semacam itu tanpa menuntut kita untuk membuat anggapananggapan yang nampak tidak realitas

b. Kelemahan Tes Statistik Non Parametrik

- Jika data telah memenuhi semua anggapan model statistik parametrik, dan jika pengukurannya mempunyai kekuatan seperti yang dituntut, maka penggunaan tes statistik non parametrik akan merupakan penghamburan data.

- Belum ada satupun metode statistik non parametrik untuk menguji interaksi-interaksi dalam model analisis varian (ANOVA), kecuali kita berani membuat anggapan-anggapan khusus tentang aditivitas.

Contoh : Penggunaan statistik non parametrik seperti pasa uji t pada parametrik diganti menjadi uji Mann Whitney ataupun Wilcoxon pada non parametrik 


\section{BAB III \\ PENUTUP}

\section{A. Kesimpulan}

Dari semua materi diatas dapat di simpulkan bahwa statistik, data, populasi, dan sampel. Dan memiliki banyak jenis statistik itu sendiri dimulai dari statistik deksriptif dan statistik inferensial maupun statistik paramentrik dan statistik non paramentrik. Dan statistik juga memiliki variable yang sangat penting di dalam statistik itu sendiri dan skala pengukuran juga yang harus di fokuskan dalam mengerjakan statistik ini.

\section{B. Saran}

Makalah ini masih sangat jauh dari kesempurnaan, baik dari segi penyajian bahan maupun dari segi penulisan. Oleh sebab itu, penulis sangat mengharapkan kritik dan saran pembaca agar karya tulis ini bisa menjadi berguna bagi Pendidikan di Indonesia. 


\section{DAFTAR PUSTAKA}

Arsyam, M(2020). Manajemen Pendidikan Islam.

Heriyanto, H(2020) Teknik menulis Artikel Konseptual.

Heriyanto. H(2020) Telah Kurikulum 2013 : Hasil Revisi Tahun 2018.

Jusmiana, A., dan Heriyanto, H. (2020). Suplemen Materi Statistik terapan dalam ilmu Kesehatan.

Sappada, A.O., dan Arsyam, M(2020) Ilmu Pengetahuan dan Teknologi menurut pandangan islam.

"An intervening variable is that factor that theoretically affect the observed phenomenon but cannot be seen, measure, or manipulate" (Tuckman,1988 dalam Sugiyono 2016),

: https://www.psikologimultitalent.com/2015/09/jenis-jenis-skala- 